Journal of Environmental and Agricultural Studies

ISSN: $2710-140$

DOI: $10.32996 /$ jeas

Journal Homepage: www.al-kindipublisher.com/index.php/jeas

JAES

\title{
The Use of Artificial Neural Network and Advanced Statistics to Model Sediment Yield on a Large Scale: Example of Morocco
}

\author{
Abdelali Gourfi ${ }^{1} \square$ Lahcen Daoudi $^{2}$, Abdelhafid El Alaoui El fels ${ }^{3}$, Abdellatif rafik ${ }^{4}$, Salifou Noma Adamou ${ }^{5}$ \\ and Ayoub Lazaar 6 \\ ${ }^{1}$ ESO-Angers, UMR 6590 CNRS, Université d'Angers, France \\ ${ }^{235}$ Laboratory of Georessources, Geoenvironnement and Civil Engineering (L3G), Faculty of Sciences and Techniques, Cadi Ayyad \\ University, B.P. 549, Marrakech, Marocco \\ ${ }^{4}$ International Water Research Institute (IWRI), Mohammed VI Polytechnic University, Ben Guerir 43150, Morocco \\ ${ }^{6}$ Dept. of Geology, Faculty of Sciences, Mohammed First University, Oujda, Morocco \\ $\square$ Corresponding Author: Abdelali Gourfi, E-mail: gourfia@gmail.com
}

ARTICLE INFORMATION ABSTRACT

Received: 08 October 2021

Accepted: 14 November 2021

Published: 21 December 2021

DOI: $10.32996 /$ jeas.2021.2.2.10

\section{KEYWORDS}

Soil erosion, Sediment yield, catchment, Neural network, Morocco.
Morocco ranks among countries with the greatest achievements in the field of dams in Africa but is affected by the sedimentation phenomenon due to soil erosion in upstreams. The assessment of Sediment Yield (SY) and Suspended Sediment Yield (SSY) remains a challenging global issue, especially in Morocco, characterized by a great diversity of morphological, climatic, and vegetation cover. The main objective of this paper was to perform advanced statistics and artificial neural networks (ANN) in order to understand the spatial distribution of sediment yield and the factors most controlling it, including factors of the RUSLE model (Revised Universal Soil Loss Equation). In order to produce a model able to assess SY, we collected and analyzed extensive data of most variables that can be affecting SY using 42 catchments of the biggest and important dams of Morocco. Statistical analysis of the studied watersheds shows that SY is mainly related to the watershed area and the length of the drainage network. On the other hand, the SSY is higher in watersheds where gully erosion is abundant and lower in areas with no soil horizon. The SSY is mainly related to the altitude, aridity index, sand fraction, and drainage network length. In front of the complexity of preserving this phenomenon, the ANN was applied and gave very good satisfactory results in predicting the SSY (NSE $\left.=0.93, \mathrm{R}^{2}=0.93\right)$.

\section{Introduction}

Soil erosion and its impacts take increasing attention from researchers and policymakers all over the world (Boardman and Poesen 2006; EC 2000; ICCD 2008; MEA 2003). Despite this, there is a significant lack of studies and data needed to assess soil erosion and the sediment delivery process. The comprehension of these phenomena remains a challenge in the environmental field (Milliman and Farnsworth 2011; Walling 1984).

Dealing with these issues, policymakers and scientists face the question of which model is most efficient to predict sediment yield SY (t.year ${ }^{-1}$ ) and area-specific sediment yield SSY (t.ha- ${ }^{-1}$.year ${ }^{-1}$ ) (EC 2000; ICCD 2008; MEA 2003). Several researchers have noted the complexity of predicting and modelling soil erosion and sediment yield (Merritt et al., 2003; Govers 2011). Accumulated sediments in reservoirs and lakes are usually used for model calibration and validation (García-Ruiz and Lana-Renault 2011; Notebaert et al., 2011).

Unlike conventional soil erosion and sedimentation estimation models, black-box models such as Recurrent Neural Networks (RNN) can encompass this estimation variability in one structure. RNN can be adopted for forecasting suspended sediment

Copyright: (c) 2021 the Author(s). This article is an open access article distributed under the terms and conditions of the Creative Commons Attribution (CC-BY) 4.0 license (https://creativecommons.org/licenses/by/4.0/). Published by Al-Kindi Centre for Research and Development, London, United Kingdom. 
concentration in river systems and present, thus, a real simple solution for modelling soil erosion and understanding controlling factors (Liu et al., 2013a; Bhattacharjee and Tollner 2016).

Due to its geographical position in the northwest of Africa, Morocco is characterized by great diversity in terms of climate, vegetation, morphology and geology; this situation makes it even more difficult to model and predict SSY for sustainable management of this phenomenon. In light of these concerns, this study's main objectives are i) application of statistical analysis to understand factors controlling their distribution iii) testing the feasibility of ANN to predict SSY.

With a total of 152 dams, Morocco is ranked among the African countries with the highest amount of dams (Alhassan 2009; Wisser et al., 2013). However, the management of water resources in dams is important, especially with the Kingdom's accentuated aridity and drought. In contrast, the soil erosion by water represents the principal cause of silting of dams, causing a dramatic decrease in water storage capacity (Gourfi et al., 2018). In this study, we expect that the detailed statistical sensitivity analysis and the neural network could provide a better understanding of the dynamics and distribution of soil erosion and contribute to identifying strategies for better sustainable management of water and soil resources.

\section{Study area}

The Morocco kingdom (710 $850 \mathrm{~km} 2)$ is located in the northwest of the African continent. (21 N to $36 \mathrm{~N}, 1 \mathrm{~W}$ to $17 \mathrm{~W}$ ). It is classified as one of the most diversified countries in terms of rainfalls (Fig. 1a), structural domains (Fig. 1b), elevations (Fig. 1c) and land cover (Fig. 1d). Morocco can be classified into four main areas: 1) the domain to the North (Rif), composed of friable rocks of various ages, dense and permanent vegetation cover, well developed thick soil, and a humid climate, 2) the Meseta area is typically characterized by gentle to moderate slopes, the Mediterranean to semi-arid climate and thick soils, 3) the domain of the Atlas Mountains is marked by high altitudes with very steep slopes, a semi-arid climate, a medium vegetation cover and undeveloped soils, and 4) the Anti-Atlas and Saharan regions are distinguished by a desert climate, very poor soils, bare areas and sparse desert steppes.

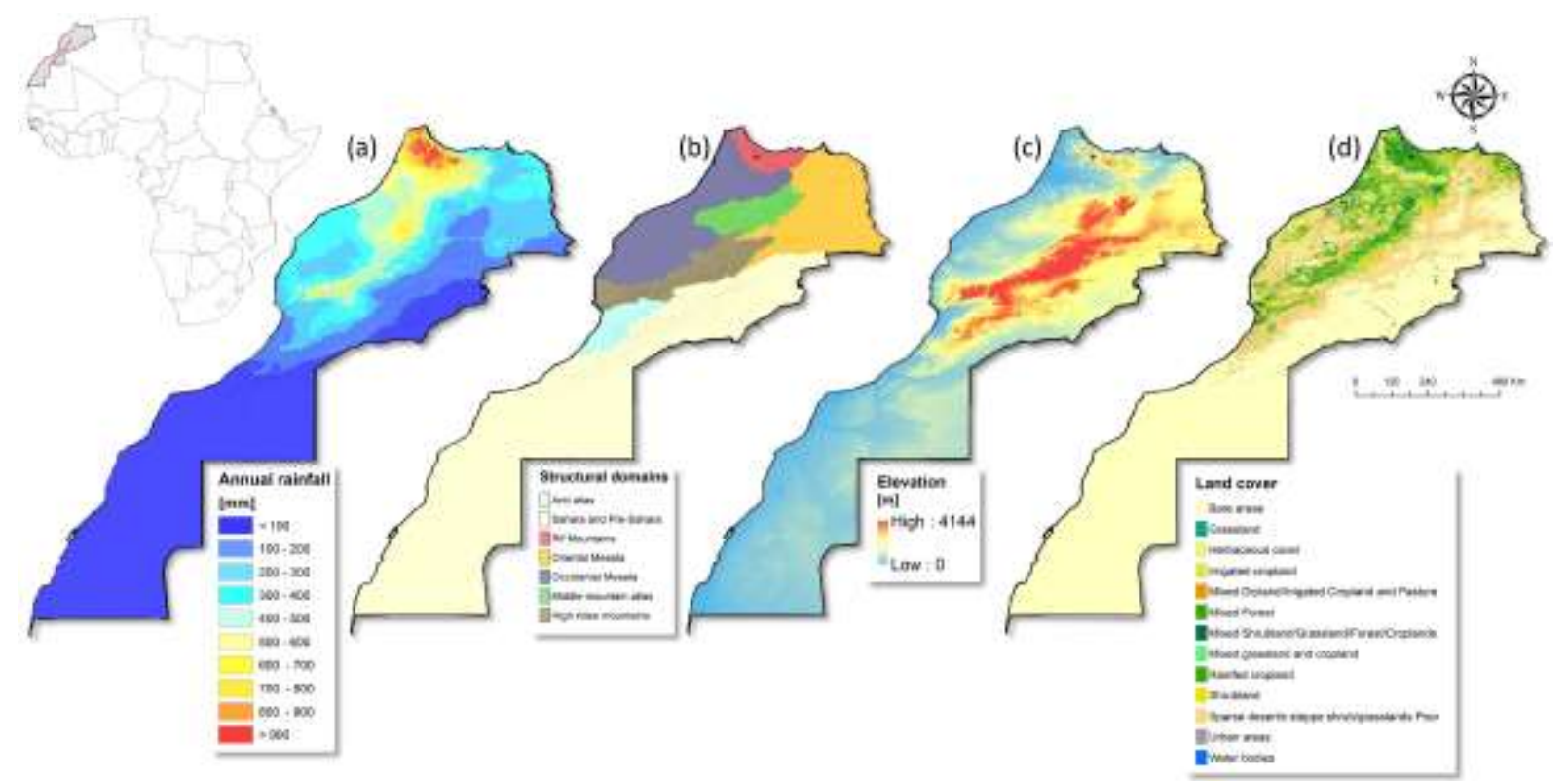

Fig. 1. (a) Rainfall (Fick and Hijmans, 2017), (b) Structural domains of Morocco (Zouhri et al., 2005; modified), (c) Elevation and (d)

3. Methodology

Land cover (ESA, 2014).

The understanding of factors controlling the sediment yields (SY) and area-specific sediment yield is done following five main steps: (1) estimation of the observed SSY and SY based on the bathymetric surveys of the studied check dams, (2) the collection of a database gathering the parameters reported as the most influential SSY and SY (3) performing the PLS model in order to develop the regression equations relation SY and its most correlated variables (4) perform a detailed sensitivity analysis of RNN in order to identify parameters that are important for predicting the SSY, (5) processing, calibration and validation of recurrent neural network.

\subsection{SY and SSY calculation}

42 of the 152 dams counted in Morocco have been selected because of the presence of sedimentation data, based on data from Gourfi et al. (2018) (Fig. 2). 
The formula suggested by Verstraeten and Poesen (1999) was used to determine the area-specific sediment yield:

$$
\mathrm{SSY}=100(\mathrm{SV} \times \mathrm{dBD}) /(\mathrm{CA} \times \mathrm{STE})(\text { eq. } 1)
$$

Where SSY is the area-specific sediment yield $\left(\mathrm{t} \cdot \mathrm{ha}^{-1} \cdot \mathrm{year}^{-1}\right), \mathrm{dBD}$ represents the dry sediments bulk density $\left(\mathrm{t} \cdot \mathrm{m}^{-3}\right)$, which was taken to be equal to $1.3 \mathrm{t} \cdot \mathrm{m}^{-3}$ in Morocco's reservoir sediments (Alahiane et al., 2016; Elmouden et al., 2017; Lahlou 1988), STE is the trap efficiency (\%), SV is the measured sediment volumetric $\left(\mathrm{m}^{3} \cdot \mathrm{year}^{-1}\right)$ and CA the basin area (ha).

The usual relation proposed by Brown (1943), relatively easy to apply and suitable for large reservoirs (eq. 2), was used to calculate STE:

$$
\mathrm{STE}=100 \times\left(1-\frac{1}{(1+\mathrm{D} \times(\mathrm{C} / \mathrm{CA})}\right)
$$

Where STE is the trap efficiency $(\%), C$ is the reservoir capacity $\left(\mathrm{m}^{3}\right), \mathrm{CA}$ is the basin area $\left(\mathrm{km}^{2}\right)$, and $\mathrm{D}$ a constant (the value 0.1 taken as a mean in the Moroccan case) (Alahiane et al., 2016; Elmouden et al., 2017).

For each outlet (dam), the basin boundaries were delineated through the digital elevation model at a resolution of 30 meters using the GIS environment.

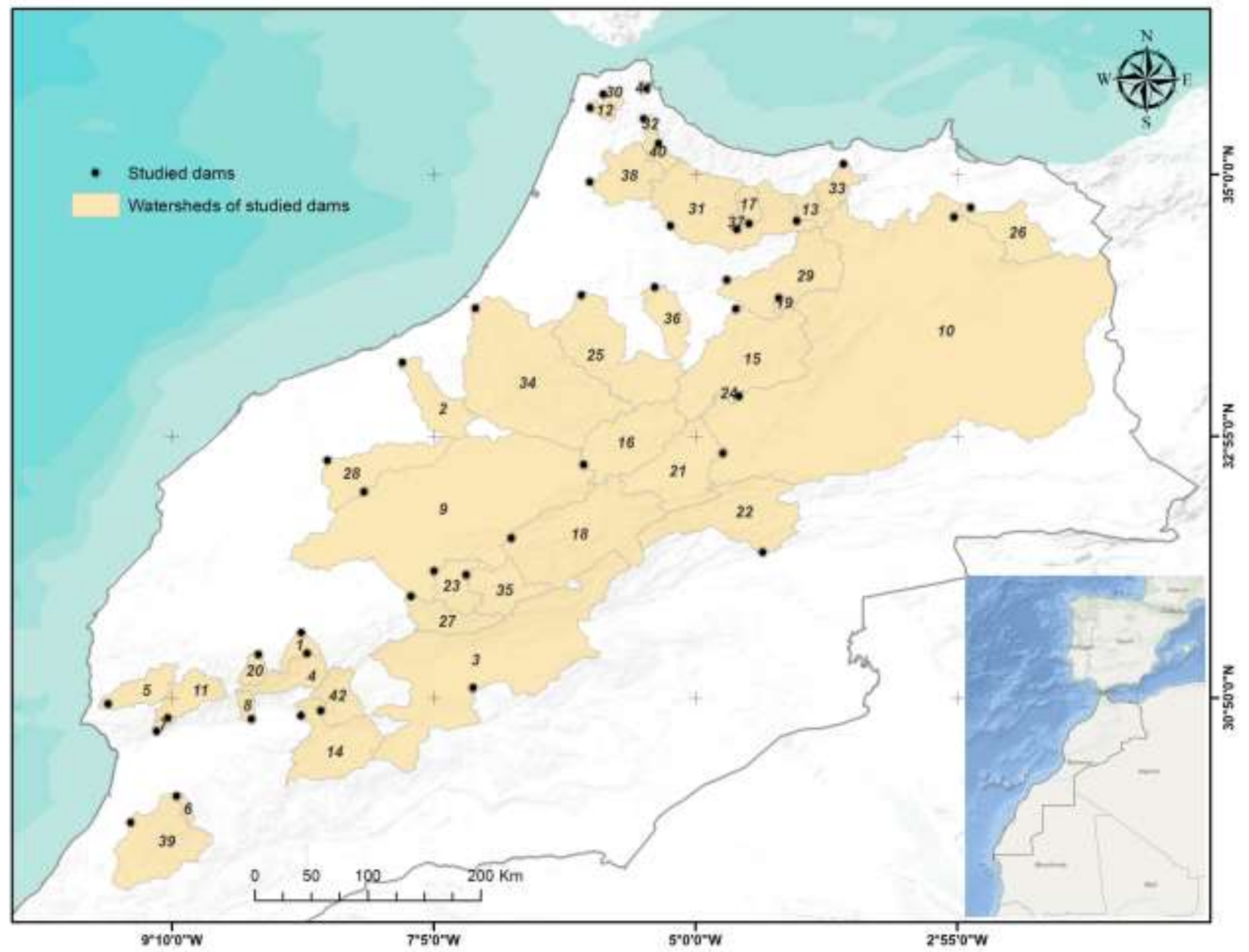

Fig. 2. Selected dams and their corresponding drainage basins (the numbers correspond to the dam references)

\subsection{Potential predictor variables}

An extensive database of 14 quantitative variables was used. These variables are described in the literature to have the greatest influence on sediment yield and soil erosion processes (Table. 1). (de Vente et al., 2011). 
The Shuttle Radar Topography Mission developed variables related to catchment morphology and drainage network using a 90 meters DEM of the USGS EROS data centre(Rabus et al., 2003).

Rainfall data is determined from the Tropical Rainfall Mapping Mission (TRMM) data (http://trmm.gsfc.nasa.gov/), using the 3B43 product (7.5 arc minutes spatial resolution) and a monthly time-step. The aridity index (10 arc minutes spatial resolution) is obtained from The Geo-Network data of the FAO (http://ref.data.fao.org).

The NDVI (Normalized Difference Vegetation Index) map at 250-meters resolution is calculated from averaging the MODIS (Moderate Resolution Imaging Spectroradiometer) time-series disponible maps (http://pekko.geog.umd.edu/usda/test/index.php).

Properties of soil, including sand, silt, clay, coarse fragment volumetric (CFV), soil organic carbon stock (SOCS), bulk density and absolute deep to bedrock, were obtained from the Soil Grids database at 250 meters(Hengl et al., 2015) (https://soilgrids.org).

\subsection{Artificial neural network}

The artificial neural network (ANN) is an approach adaptable to predicting and modelling nonlinear behaviour; it has received a great deal of attention in the last few decades as an effective computation tool in forecasting hydrology and sediment delivery processes (Liu et al., 2013b).

Artificial neural networks (ANN) are rarely used in soil erosion modelling (Jain, 2001; Nagy et al., 2002; Bhattacharjee and Tollner, 2016), although their application is extremely beneficial in many other disciplines. Compared with other types of ANNs, the multilayer perceptron (MLP) or feedforward network is less complex, and it is the most widely used type in the ANN family. It covers the majority of scientific and industrial applications. It is a layer-propagation network model (Figure. 3) in which neurons are classified into several successive layers: an input layer, one or more intermediate layers, also called hidden layers, and finally, an output layer.

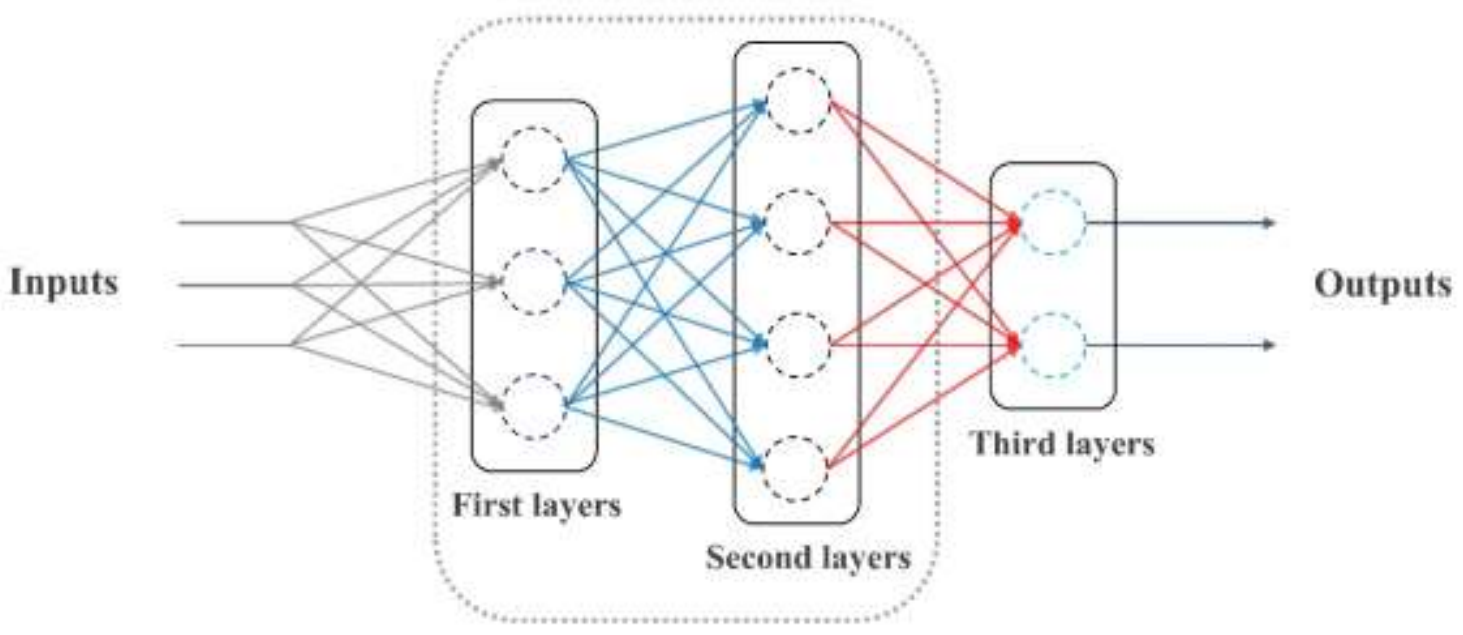

Hidden layers

Fig. 3. The artificial neuron structures

MLP neural network modelling aims to find the best structure of the connection weights between neurons to associate an adequate response to each input configuration. The modelling is done in two steps. First of all, a learning phase (calibration) is done where the network must find by itself the underlying regularities of the data; it is a matter of determining the weight values, which enable it to obtain the best performance for a given criterion by minimizing the error between the observed and simulated data, this calibration is obtained by the back-propagation algorithm of the error gradient. The second phase is validation. In this phase, we test the model's ability to simulate data outputs that were taken different from those taken in the first step. 


\subsection{Sensitivity analysis of ANN and predictions accuracies}

The main objective of sensitivity analysis is to get knowledge of the relationship among output and input parameters in a model by ranking the input variables and quantifying their influence on output variables prediction (Bhattacharjee and Tollner, 2016). In this study, the sensitivity analysis is estimated using the "Neural Net Tools" package in R (Beck, 2018), based on the Garson's Algorithm (Garson, 1991).

The method proposed by (Garson 1991) is based on partitioning the weights of neural network connections. In order to quantify the influence of inputs on the output, the algorithm reports the relative importance of each input variable expressed as a percentage. The algorithm uses absolute values of connection weights, and it can be applied only to neural networks with one output variable.

The predictions accuracies of all regression equations were evaluated using two common criteria; the coefficient of determination $\left(R^{2}\right)$ and Nash-Sutcliffe efficiency coefficient (NSE). The NSE and R² are calculated as ( Nash and Sutcliffe, 1970; Bennett et al., 2013;):

$$
\begin{gathered}
\text { NSE }=1-\frac{\sum_{i=1}^{N}\left(O_{i}-P_{i}\right)^{2}}{\sum_{i=1}^{N}\left(O_{i}-\bar{O}\right)^{2}} \text { eq. 4) } \\
R^{2}=\left(\frac{\sum_{i=1}^{N}\left(O_{i}-\bar{O}\right)\left(P_{i}-\bar{P}\right)}{\sqrt{\sum_{i=1}^{N}\left(O_{i}-\bar{O}\right)^{2} \sum_{i=1}^{N}\left(P_{i}-\bar{P}\right)^{2}}}\right)^{2}(\text { eq. 5) }
\end{gathered}
$$

$\mathrm{N}$ is the considered number of data points; Oi and Pi are, respectively, the observed and predicted value, and $\overline{\mathrm{O}}$ and $\overline{\mathrm{P}}$ are their means;

The closer the $\mathrm{R}^{2}$ and NSE approach to 1, the more the model is efficient.

\section{Results and Discussion}

\subsection{Spatial distribution of sediment yield SY and area-specific sediment yield SSY}

The distribution map of SY $\left(\mathrm{Mt}^{3} \cdot \mathrm{year}^{-1}\right)$ and SSY $\left(\mathrm{t} \cdot \mathrm{ha}^{-1} \cdot \mathrm{year}^{-1}\right)$ was illustrated in Fig. 4. Results show a mean SY of $1.96 \mathrm{Mt} \cdot \mathrm{year}^{-1}$, recording as the highest value of SY $15.08 \mathrm{Mt}^{3}$.year-1, the lowest value recorded is $0.04 \mathrm{Mt}^{3}$.year ${ }^{-1}$. The average SSY is $6.40 \mathrm{t}^{\mathrm{t}}$.ha- $\mathrm{ha}^{-1}$.year ${ }_{1}^{1}$, the lowest value is $1.02 \mathrm{t} \cdot \mathrm{ha}^{-1} \cdot \mathrm{yr}^{-1}$, and the highest value is $55.25 \mathrm{t} \cdot \mathrm{ha} \mathrm{a}^{-1} \cdot \mathrm{year}^{-1}$. The majority of watersheds experiencing high SSY are located in the North; these watersheds are generally characterized by a Mediterranean climate, dense vegetation and located in the Rif; the presence of the friable lithology in these areas induces spectacular gully soil erosion (Gourfi et al., 2018).

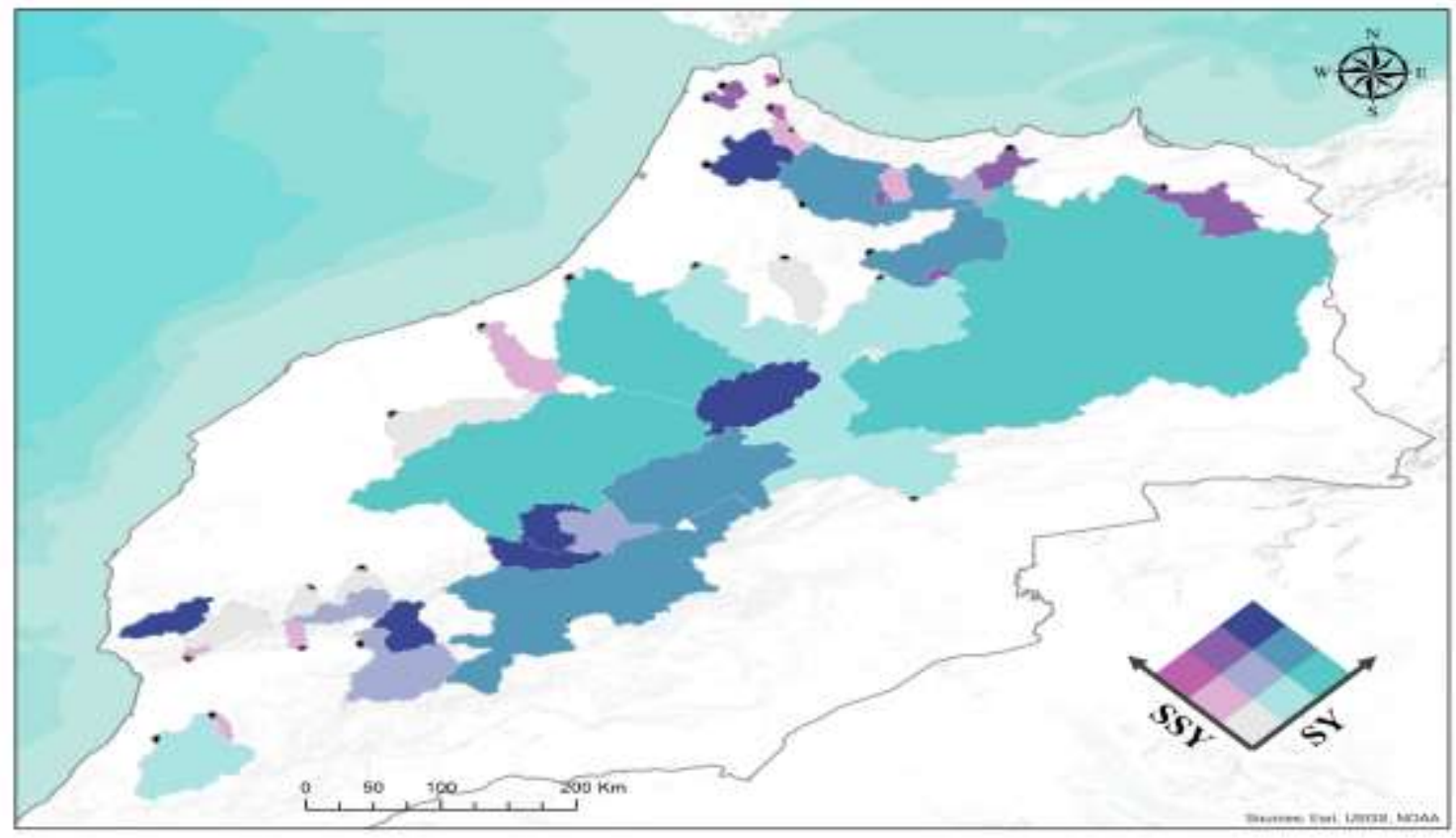

Fig. 4. Distribution of SY and SSY by corresponding drainage basins of the studied dams. 


\subsection{Correlation analysis results}

The correlation between Area-Specific Sediment Yield, Sediment Yield and catchment properties shows information about relations existing between some variables (Fig. 5), most relevant remains the existing relation between rainfall and soil organic carbon stock $(r=0.88)$, the observed sediment yield and catchment area $(r=0.74)$, silt content and NDVI $(r=0.78)$.

A set of founded high correlations between some variables show the existing collinearity between them. For example, the Aridity index, Rainfall, NDVI and Soil organic carbon stock are highly correlated, also, drainage network length, catchment area and drainage density.

Only a few factors are meaningfully correlated with SY; drainage network length and basin area were the most explanatory variables correlated with SY ( 0.74 and 0.73 , respectively). The SSY shows as a most important positive correlation with the NDVI and SOCS (0.56 and 0.53 respectively), a moderate negative correlation is observed between SSY and drainage density, drainage network and catchment area $(-0.55,-0.53$ and -0.52 , respectively).
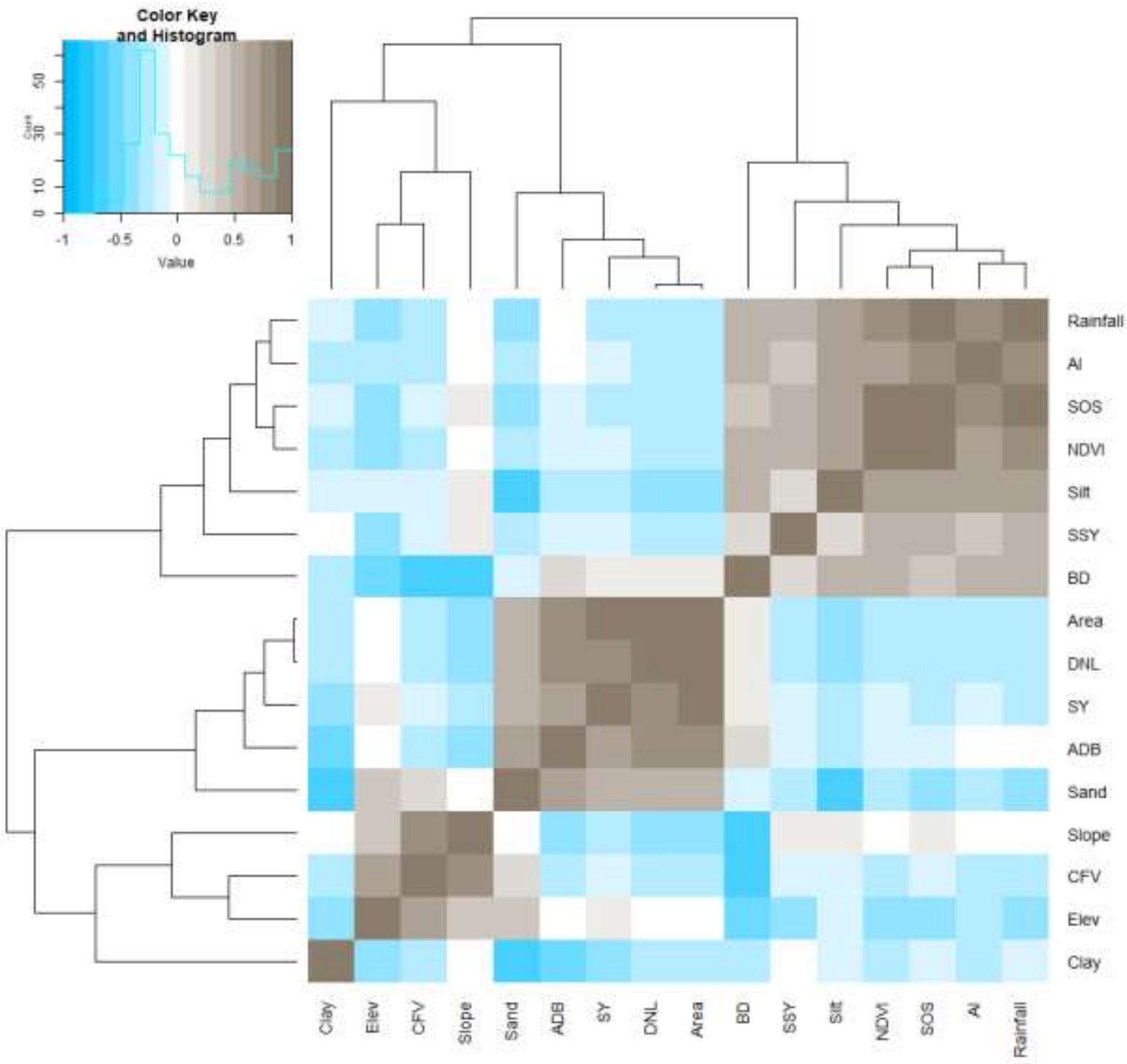

Fig. 5. Correlation matrix of all tested variables.

\subsection{Major groups of watersheds in Morocco}

The Principal Component Analysis (PCA) application decorticates the watershed in Morocco into five major categories. Each category is characterized by a vegetation cover, a climate and geography. The PCA also allowed the understanding of parameters having a close relationship with these groups (Fig.6). 
The PCA, including the studied variables, identified three main end members (Fig. 6A). The first end member is positively loading correlated to the first principal component of the PCA (PC1 axis, $35.9 \%$ of the variance), presenting high positive loadings for rainfall, SOCS, NDVI, aridity index (AI), and silt. The second end member has a negative correlation for the first principal component and positive loadings for the second principal component (PC2 axis, $25.6 \%$ of the variance) and includes absolute deep to bedrock (ADB), drainage network length (DNL), catchment area (Area) and sand. The third major pool is negatively correlated with the first and second principal components and includes coarse fragment volumetric (CFV), elevation, and slope.

Results of observations in PCA (Fig. 6B) show five major populations. The first population concerns basins of the Pre-Saharan area and Saharan domain. It is characterized by gentle slopes, poor vegetation cover and low precipitations volumes, with a close variation to the sand fraction variable. The second group is related to watersheds in the mountains of the High Atlas. They are characterized by steep slopes, hard lithology and high annual precipitations volumes. Those watersheds have a close variation with Slope, CFV and elevation variables. The third population regroups to watersheds located at the north part, characterized by steep slopes, high precipitation rates, soft lithology and dense vegetation, with a close variation to the variables aridity index, silt fraction, NDVI, SOCS and rainfall. The fourth population is related to basins in the occidental Meseta characterized by flatlands, medium precipitation rates and vegetation cover. The last group (population 5) is related to watersheds located at the Oriental Meseta characterized by flatlands, low precipitation rates and vegetation cover. The last two groups (groups 4 and 5) have a close variation with drainage density, catchment area, absolute depth to bedrock, and drainage network length.

\section{A: Variables}

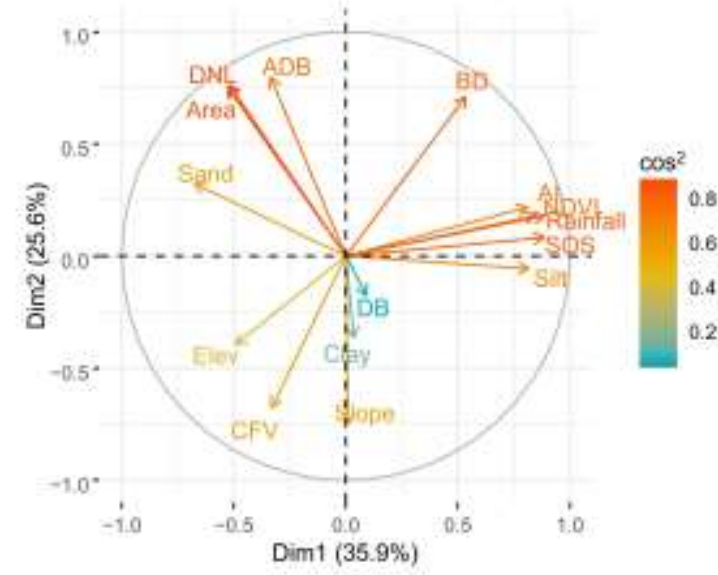

B: Individuals

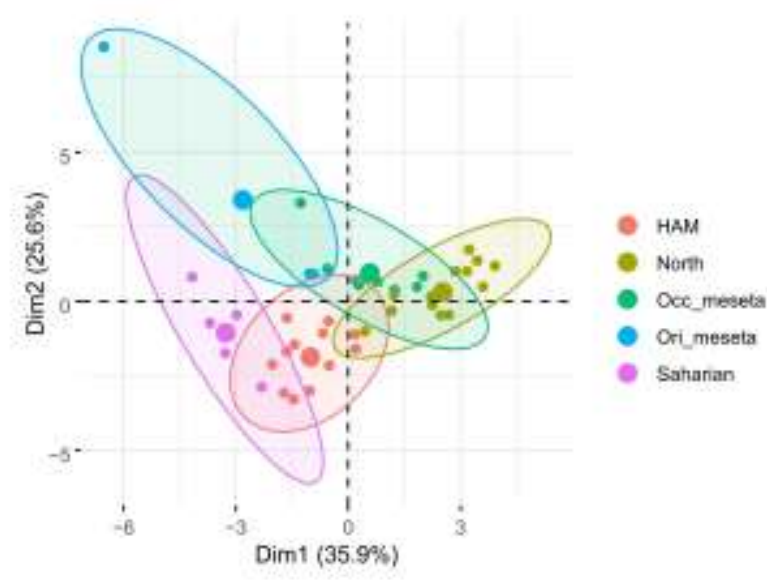

\subsection{PLS application results}

Fig. 6. Results of ACP application A) Variables B) Individuals

The application of the correlation analysis (Fig. 5) shows that drainage network length and catchment area have the closest relation to sediment yield, with respective correlations of $r=0.73$ and $r=0.74$. Based on the model efficiency and fit, the developed regression equations by the partial least squares Regression model can provide accurate predictions of sediment yield in relation to these two variables (Fig. 7):

$$
\begin{gathered}
\mathrm{SY}\left(\mathrm{Mt}^{3} \cdot \mathrm{yr}^{-1}\right)=6.66 \cdot 10^{-4} \mathrm{DNL}(\mathrm{km})+0.92(\text { eq. } 6) \\
(\text { with } \mathrm{R}=0.73 \text { and } \mathrm{NSE}=0.77) \\
\mathrm{SY}\left(\mathrm{Mt}^{3} \cdot \mathrm{yr}^{-1}\right)=3.20 \cdot 10^{-4} \mathrm{CA}\left(\mathrm{km}^{2}\right)+0.82 \text { (eq. } 7 \text { ) }
\end{gathered}
$$

(with $\mathrm{R}=0.74$ and $\mathrm{NSE}=0.79$ ) 


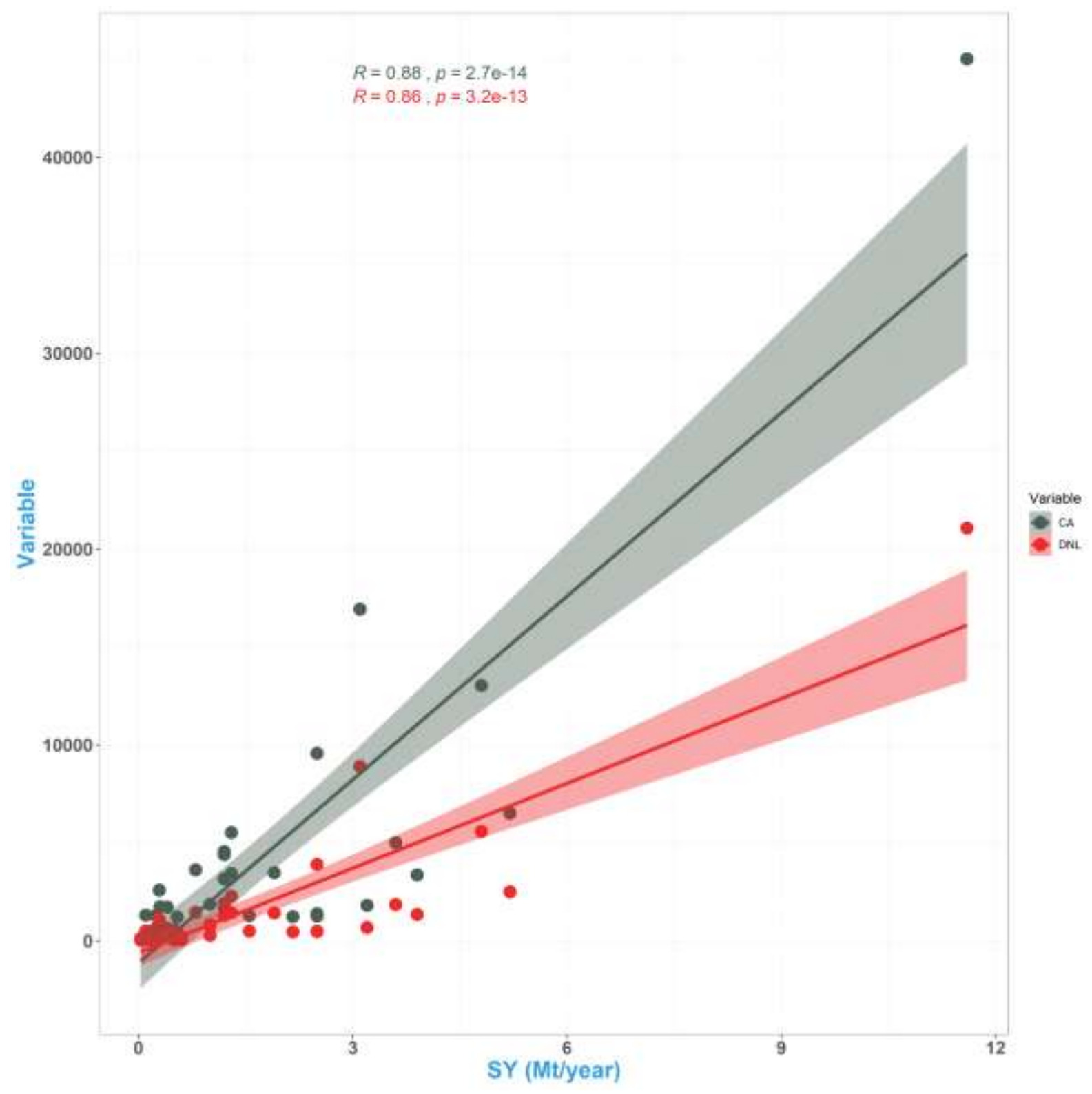

Fig. 7. Observed SY in relation to the catchment area (CA) and drainage network length (DNL).

\subsection{Neural network application}

After several tests and after having obtained the maximum value of Nash and correlation performance criteria, the architecture of the neural network model most relevant for the simulation of area-specific sediment (SSY) is of type [15-5-1] (Figure 8A). The model is thus, composed of an input layer of 15 neurons, a hidden layer containing five neurons and an output layer containing a single neuron. In the calibration phase, the dams with references from 1 to 20 were taken; in this step, the results of comparing the observed SSY and simulated ones by the application of the AAN are shown in figure $8 \mathrm{~B}$; the predictions show very good results with a Nash criterion of NSE $=0.97$, and a correlation coefficient of $\mathrm{R}^{2}=0.97$.

The analysis of the results in this phase (Figure $8 C$ ) shows a good simulation of SSY (NSE $=0.93 ; R^{2}=0.93$ ). This ability validates the applicability of this model for the prediction of area-specific sediment.

The performed sensitivity analysis using Garson's Algorithm (Garson, 1991), the most important input variables are area-specific sediment prediction, drainage network length (DNL), Sand, Aridity index, and Elevation are the most (Fig. 8D). 


\section{A}

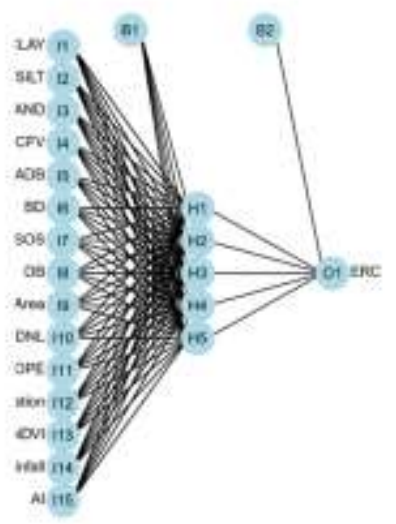

B

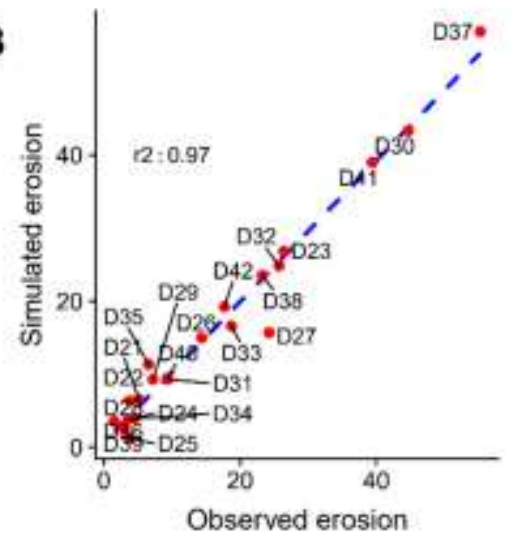

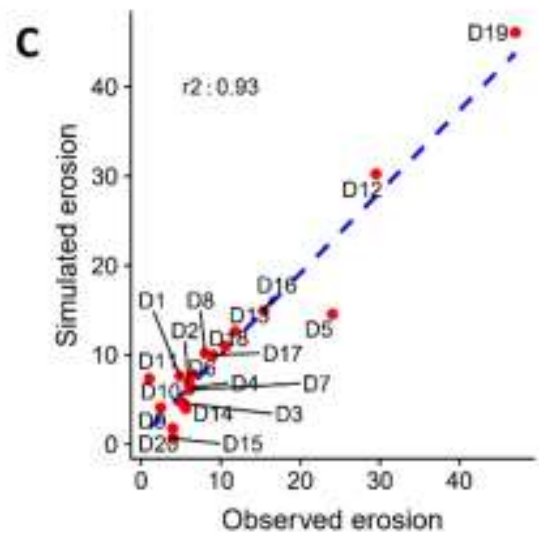

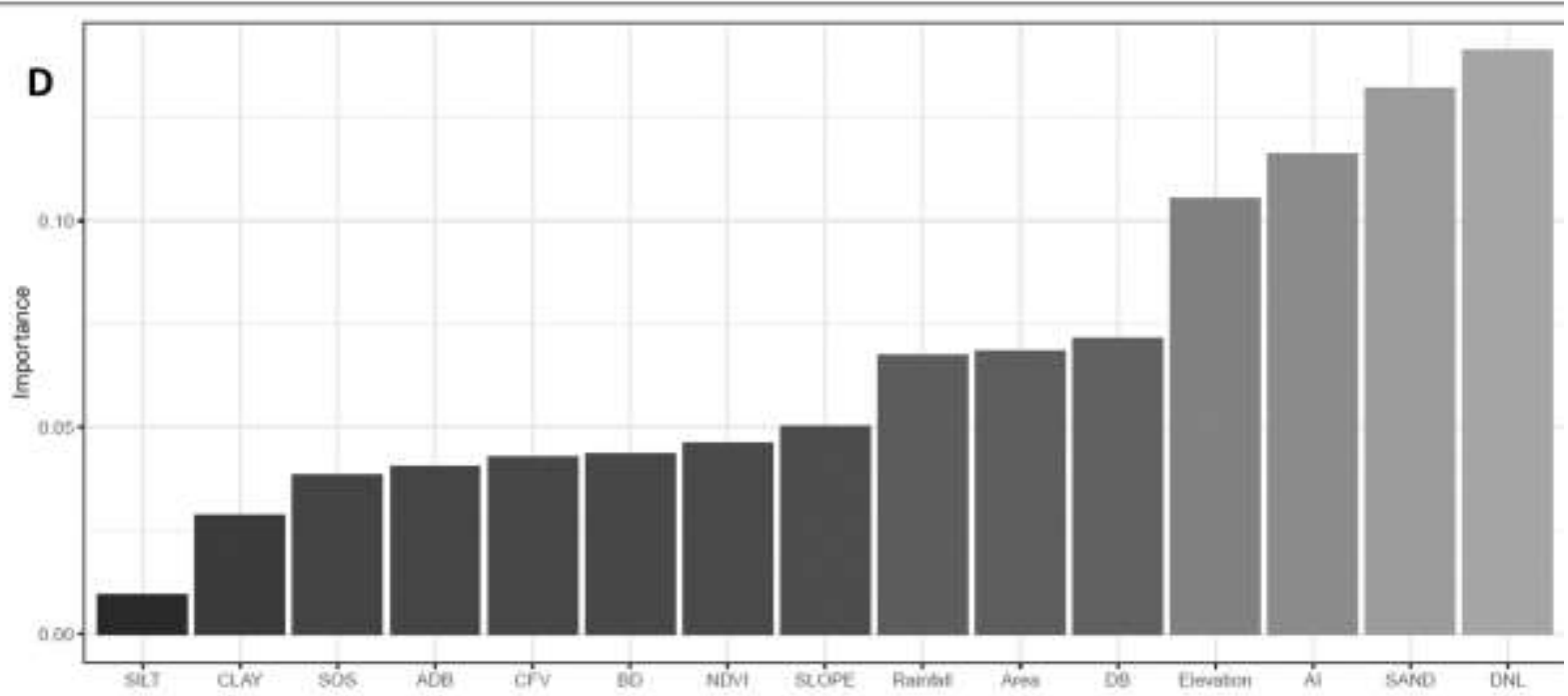

Fig. 8. A) Artificial Neural network architecture, B) Calibration, C) Validation D). Sensitivity Analysis for Output variable using Garson's algorithm

\section{Discussion}

\subsection{Modelling SSY difficulties}

Most SE and SSY models cannot simulate the feedback between erosion, deposition and landform (De Vente et al., 2013). In fact, most models designed to simulate sediment transport and deposition are often calibrated using data collected from erosion plots (Licciardello et al., 2009; Nearing 2006). As a result, application at the watershed scale remains a complex task due to the interaction and complexity between processes and the lack of input data (Merritt et al., 2003; De Vente and Poesen, 2005; Morgan and Nearing, 2011).

Conceptual, traditional empirical and physics-based or regression models didn't prove the ability to estimate processes controlling sediment yield due to unfeasible required data and insufficient systems knowledge and often do not represent all involved soil erosion processes. Generally, most experiential models are based on RUSLE (Revised Universal Soil Loss Equation) (Renard et al., 1997) and were developed to predict soil losses generated by rill and/or sheet erosion. As sediment deposition is not considered (Wischmeier 1976; Boardman and Poesen 2006), not either permanent gullies and landslides (Verstraeten et al., 2003), such models cannot be used to predict catchment SSY (De Vente et al., 2013).

Most SE and SSY models assume equilibrium between soil formation and their removal by water erosion, ignoring feedback mechanisms and the topography change (Coulthard et al., 2002).

Other limitations maybe not taking into consideration is the Sediment Delivery Ratio (SDR) (Van Rompaey et al., 2005; De Vente et al., 2008) and seismic activity, which may play an important role in explaining SSY through the triggering of landslides (Hovius et al., 2000, 2011; Montgomery and Brandon, 2002). 
As mentioned by (De Vente et al., 2013), a great cause why some models still provide acceptable estimates of SY after the calibration is that these over-estimate hillslope compensate for undescribed erosion processes.

\subsection{Modelling SY and SSY on the national scale}

Although the seriousness of the problem, very few studies have characterized and assessed the phenomenon of soil erosion and sedimentation of dams in Morocco (Badraoui and Ahmed, 2001; Gourfi et al., 2020; Gourfi and Daoudi, 2019; Gourfi et al., 2018; Gourfi et al., 2020), This is mainly due to the lack of recurrent data and the interaction and complexity of erosion-sedimentation processes (Merritt et al., 2003; De Vente et al., 2013; de Vente and Poesen, 2005).

In Morocco, the sediment yield rates in reservoirs are mainly related to the catchment areas and the drainage networks. The founded results go with those of (Milliman and Syvitski, 1992), which found that the catchment area has the strongest influence on sediment yield in most rivers. This is especially due to a general increase in catchment size with flow magnitude and the cumulative sediment delivery at the downstream outlet. Also, many other researchers have described this relation ( Verstraeten and Poesen, 2001; Rymszewicz et al., 2018).

The major limitation in the prediction of SSY is the non-consideration of permanent gullies and mass movements and absence of soil erosion ( De Vente et al., 2013; Gourfi et al., 2018); in this study, we evaluated the amounts of SSY compared to the tree conditions; ordinary conditions areas, gully erosion abundance areas and poor or absence of soil horizon areas (Figure. 9). Gully erosion abundance recorded the highest rates of SSY, with a mean of $31.67 \mathrm{t} \cdot \mathrm{ha}^{-1}$.year ${ }^{-1}$, areas of ordinary conditions has recorded moderate rates of SSY with an average of $7.30 \mathrm{t}_{\mathrm{tha}}^{-1}$.year ${ }^{-1}$, an area with poor or absence of soil erosion recorded the lowest average with $5.32 \mathrm{t} \cdot \mathrm{ha}^{-1}$.year-1. These results confirm other hypotheses suggesting that the gullies and mass movements processes are the biggest contributors to total sediment yield (80\%), especially in the Mediterranean and mountainous areas (Plata-Bedmar et al., 1997; Trimble, 1999; De Vente et al., 2008 and 2013; Vanmaercke et al., 2011).

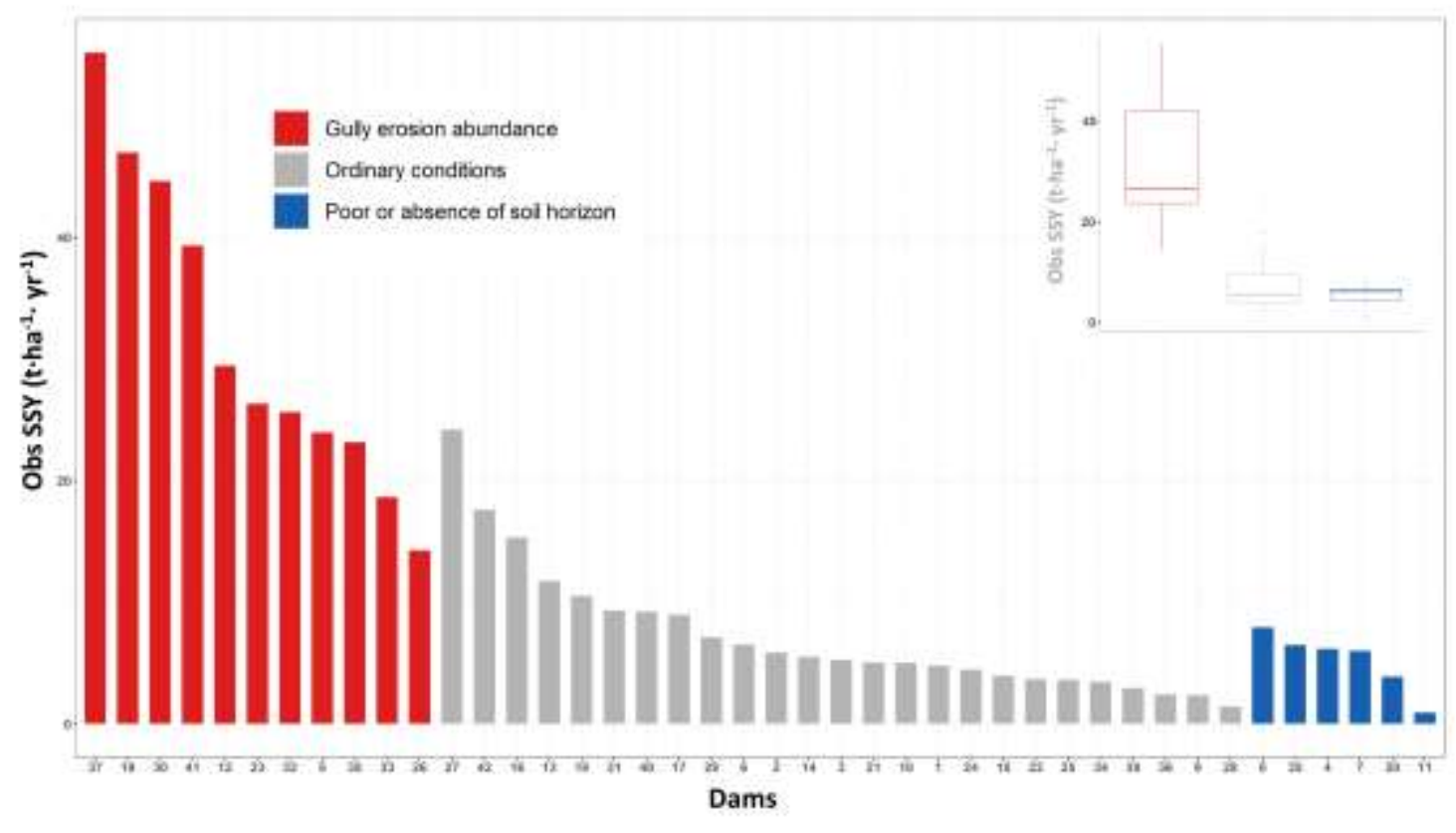

Fig. 9. Studied watersheds dams and their observed SSY according to ordinary, gully erosion abundance and poor or absence of

\subsection{Application of RUSLE model on a national scale} soil horizon areas

Most empirical models are based on the Revised Universal Soil Loss Equation (RUSLE, (Renard et al., 1997)) developed initially to predict the annual soil loss due to rill and sheet erosion on hillslopes.

Morocco is characterized by a high environmental diversity and the presence of several forms of soil erosion that the RUSLE model is unable to model, mainly in the area known with soft lithologies, inducing spectacular gully erosion ( Rouai and Jaaidi, 2003; Poujol et al., 2014) (Figure. 10A), and area with poor or practically absence of soil erosion (Figure. 10B). 


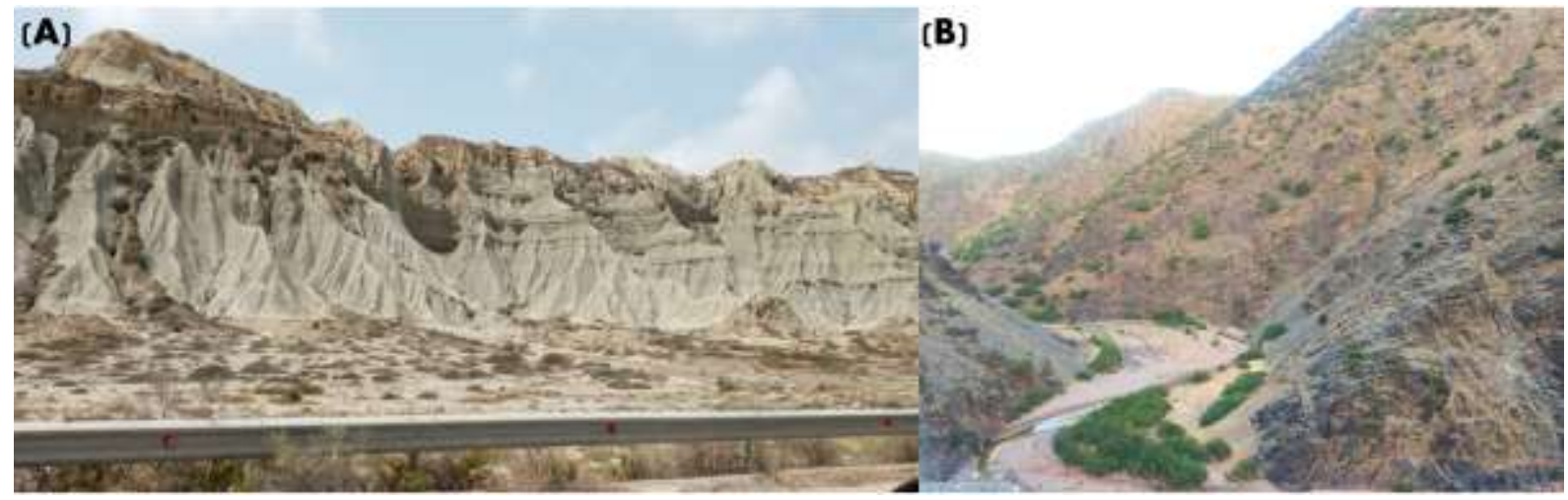

Fig. 10. Example of an area characterized by gully erosion (Rif area) (A), a poor or absence of soil horizon areas (High Atlas Mountains) (B).

In fact, the only available study that tried to model area-specific sediment yield at the national scale is that of (Gourfi et al., 2018). This study showed the inability of the RUSLE model to predict SSY. Indeed, by comparing observed SSY with modelled ones obtained using RUSLE (Figure. 11), the model showed a good ability to estimate SSY in ordinary conditions ( $r=0.77)$; the model underestimates SSY at the gully erosion abundance areas demonstrated by a very low correlation index $(r=-0.04)$, in areas characterized by poor or absence of soil horizon the model underestimates SSY evidenced by a very low correlation index $(r=-0.07)$.

These results confirm the results of many researchers that reported the inability of such models to predict SSY (Boardman and Poesen 2006; Wischmeier 1976).

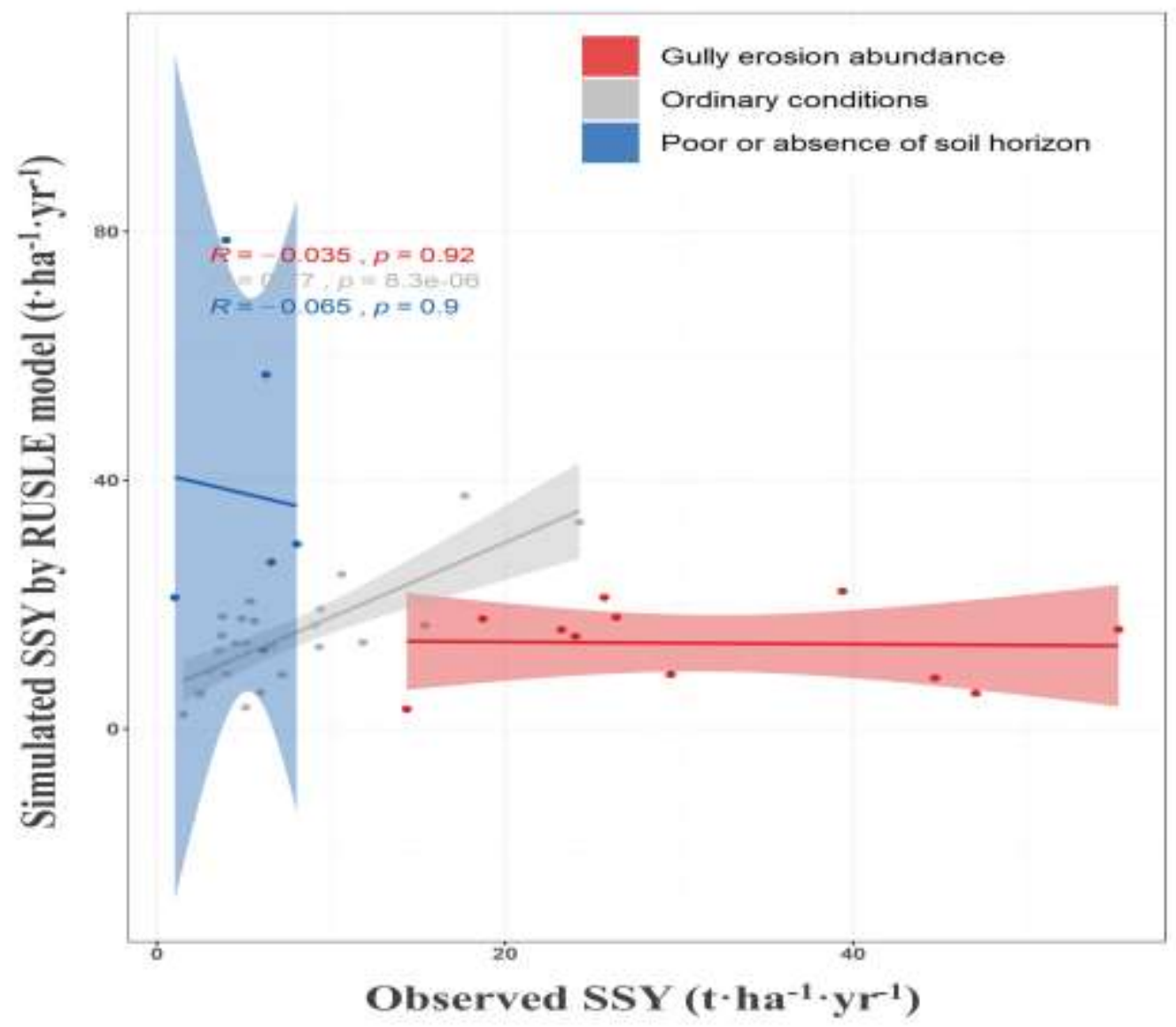

Fig. 11. Relation between simulated and observed SSY for various conditions (Gourfi et al., 2018) 
The analyses of ordinary conditions, presence of gully erosion conditions, and absence or poor soil horizon conditions (Figure. 12) in relation to environmental diversity entities shows that area with ordinary conditions represent most of the cases and compose the totality of Occidental Meseta and Saharan areas, in this respect, the RUSLE model can be applied for valuable estimations for SSY in these areas. However, we recommend its application cautiously in Oriental Meseta; in contrast, it would be better not to apply it in the North and High Atlas mountains areas, dominated by gully erosion or/and poor or absence of soil horizon.

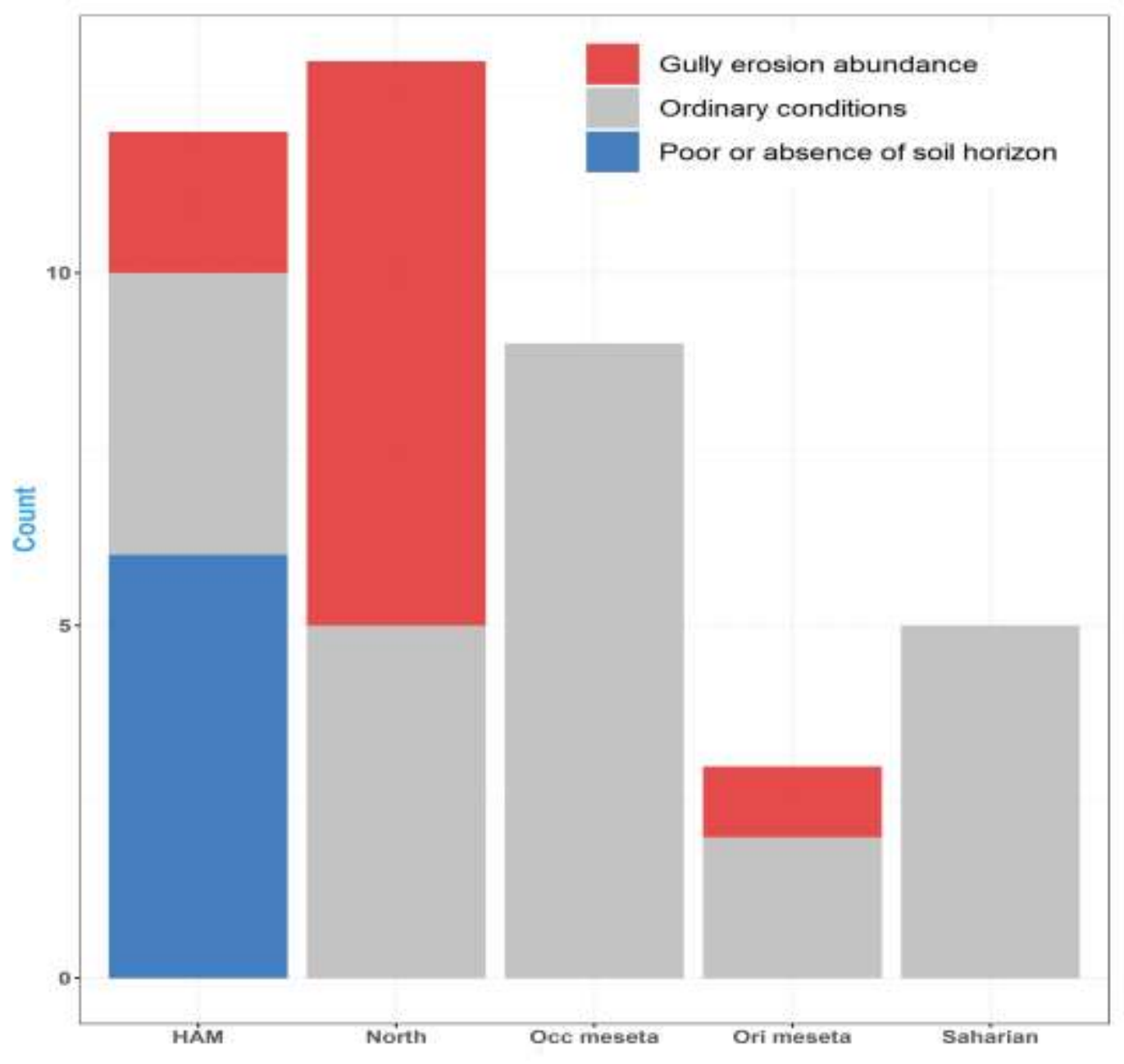

Fig. 12. Number of watersheds compared to geomorphic zones according to ordinary, gully erosion abundance and poor or absence of soil horizon areas

\subsection{Neural network application}

The description and modeling of SSY in all its forms is still a major challenge worldwide (Poesen, Torri, and Van Walleghem 2011; Wainwright et al., 2008). This work proposes the application of artificial neural networks of the black box type as a simple approachable to estimate SSY. The approach results give satisfactory results. This study will not be only a solid dataset for responsible regional policy and decision-makers, a benchmark indicator on sediment yield and area-specific sediment yield in Morocco, but also more comprehensive and accurate than those derived in previous assessments.

As the determination of area-specific sediment yield, most affecting factors always remain a challenging issue (De Vente et al., 2013), the sensitivity analysis of artificial network was applied. However, to our knowledge, only very few studies have applied ANN to predict sediment yield. Moreover, (Liu et al., 2013a)adopted ANN in order to forecast suspended sediment concentration in a river system and prove its effectiveness in predicting the phenomenon. (Kisi et al., 2006) and (Rajaee et al., 2009) and support the conclusion that ANN handles nonlinear and nonstationary intervention of SSY controlling variables better than many other models.

However, the ANN predictions give very satisfactory results compared to observed outputs; on the other hand, drainage network length (DNL), sand, aridity index (Al) and elevation are the most significant input variables contributing to the outputs. 


\section{Conclusion}

This study constructed a database of sediment yield and area-specific sediment yield for the most important Moroccan dams catchments. Additionally, a dataset of most SY and SSY controlling variables was constructed in order to emphasize most controlling factors a set of statistical processing coupled with the application of ANN to reach this objective. Concerning SY, results highlighted the good linear relation found between SY and catchment size and drainage network length. Furthermore, the modelling SSY remains a difficult issue worldwide, especially in an area like Morocco characterized by a large landscape diversity. Some areas are characterized by the absence of soil horizon, and others are dominated by landslides and gully erosion. RUSLE model didn't show the ability to model SSY in these conditions, but nevertheless, the model still gives good results under ordinary conditions. In the light of these concerns, the sensitivity analysis of ANN was applied; ANNs gave very good results and represented an efficient solution to the very diversified landscape of the area, where drainage network length, aridity index and elevation remain the most significant factors infecting SSY. The application of ANNs able to assess sediment yield in the light of the difficulty to estimate this one, especially in a country known for great morphological, climatic and vegetation diversity.

Conflicts of Interest: The authors declare no conflict of interest.

Funding: This research received no external funding.

Abdelali Gourfi ORCID : iD (0000-0003-3487-2870)

\section{References}

[1] Alahiane, N., Elmouden, A., Aitlhaj, A. \& Boutaleb, S. (2016). Small dam reservoir siltation in the Atlas Mountains of Central Morocco: analysis of factors impacting sediment yield. Environmental Earth Sciences. https://doi.org/10.1007/s12665-016-5795-y

[2] Alhassan, H. S. (2009). Viewpoint - Butterflies vs Hydropower: Reflections on large dams in contemporary Africa. Water Alternatives.

[3] Badraoui, A. \& Ahmed, H. (2001). Envasement des retenues de barrages. Houille Blanche. https://doi.org/10.1051/lhb/2001073

[4] Beck, M. W. (2018). NeuralNetTools: Visualization and analysis tools for neural networks. Journal of Statistical Software, 85. https://doi.org/10.18637/jss.v085.i11

[5] Bennett, N. D., Croke, B. F. W., Guariso, G., Guillaume, J. H. A., Hamilton, S. H., Jakeman, A. J., Marsili-Libelli, S., Newham, L. T. H., Norton, J. P., Perrin, C., Pierce, S. A., Robson, B., Seppelt, R., Voinov, A. A., Fath, B. D. \& Andreassian, V. (2013). Characterizing the performance of environmental models. Environmental Modelling and Software. https://doi.org/10.1016/j.envsoft.2012.09.011

[6] Bhattacharjee, N. V. \& Tollner, E. W. (2016). Improving management of windrow composting systems by modelling runoff water quality dynamics using recurrent neural network. Ecological Modelling, 339, 68-76. https://doi.org/10.1016/j.ecolmodel.2016.08.011

[7] Boardman, J. \& Poesen, J. (2006). Soil Erosion in Europe: Major Processes, Causes and Consequences. In Soil Erosion in Europe. https://doi.org/10.1002/0470859202.ch36

[8] Coulthard, T. J., Macklin, M. G. \& Kirkby, M. J. (2002). A cellular model of Holocene upland river basin and alluvial fan evolution. Earth Surface Processes and Landforms, 27(3). https://doi.org/10.1002/esp.318

[9] de Vente, J. \& Poesen, J. (2005). Predicting soil erosion and sediment yield at the basin scale: Scale issues and semi-quantitative models. Earth-Science Reviews. https://doi.org/10.1016/j.earscirev.2005.02.002

[10] De Vente, J., Poesen, J., Verstraeten, G., Govers, G., Vanmaercke, M., Van Rompaey, A., Arabkhedri, M. \& Boix-Fayos, C. (2013). Predicting soil erosion and sediment yield at regional scales: Where do we stand? In Earth-Science Reviews. https://doi.org/10.1016/j.earscirev.2013.08.014

[11] de Vente, J., Poesen, J., Verstraeten, G., Van Rompaey, A. \& Govers, G. (2008). Spatially distributed modelling of soil erosion and sediment yield at regional scales in Spain. Global and Planetary Change, 60(3-4). https://doi.org/10.1016/j.gloplacha.2007.05.002

[12] de Vente, J., Verduyn, R., Verstraeten, G., Vanmaercke, M. \& Poesen, J. (2011). Factors controlling sediment yield at the catchment scale in NW Mediterranean agroecosystems. Journal of Soils and Sediments. https://doi.org/10.1007/s11368-011-0346-3

[13] Defourny, P., Bontemps, S., Lamarche, C., Brockmann, C., Boettcher, M., Wevers, J., Kirches, G. \& Santoro, M. (2017). Land Cover CCI Product User Guide - Version 2.0. ESA.

[14] EC. (2000). Directive 2000/60/EC of the European Parliament and of the Council of 23 October 2000 establishing a framework for Community action in the field of water policy. Official Journal of the European Parliament. https://doi.org/10.1039/ap9842100196

[15] Elmouden, A., Alahiane, N., El Faskaoui, M. \& El Morjani, Z. E. A. (2017). Dams siltation and soil erosion in the Souss-Massa River basin. In Handbook of Environmental Chemistry. https://doi.org/10.1007/698_2016_70

[16] Fick, S. E. \& Hijmans, R. J. (2017). WorldClim 2: new 1-km spatial resolution climate surfaces for global land areas. International Journal of Climatology. https://doi.org/10.1002/joc.5086

[17] García-Ruiz, J. M. \& Lana-Renault, N. (2011). Hydrological and erosive consequences of farmland abandonment in Europe, with special reference to the Mediterranean region - A review. In Agriculture, Ecosystems and Environment. https://doi.org/10.1016/j.agee.2011.01.003

[18] Garson, G. D. (1991). Interpreting neural-network connection weights G. David Garson. Artificial Intelligence Expert, 4(6), 1-7.

[19] Gourfi, A. \& Daoudi, L. (2019). Earth Science \& Climatic Change Effects of Land Use Changes on Soil Erosion and Sedimentation of Dams in Semi-Arid Regions: Example of $\mathrm{N}^{\prime}$ Fis Watershed in Western High Atlas. Journal of Earth Science \& Climatic Change, 10(1), 1-12. https://doi.org/10.4172/2157-7617.1000513

[20] Gourfi, A. \& Daoudi, L. (2019). Effects of land-use changes on soil erosion and sedimentation of dams in semi-arid regions: example of N' Fis Watershed in Western High Atlas. Journal of Earth Science \& Climatic Change, 10(1), 1-12. https://doi.org/10.4172/2157-7617.1000513

[21] Gourfi, A., Daoudi, L. \& de Vente, J. (2020). A new simple approach to assess sediment yield at a large scale with high landscape diversity: an example of Morocco. Journal of African Earth Sciences. https://doi.org/10.1016/j.jafrearsci.2020.103871 
[22] Gourfi, A., Daoudi, L., Rhoujjati, A., Benkaddour, A. \& Fagel, N. (2020). Use of bathymetry and clay mineralogy of reservoir sediment to reconstruct the recent changes in sediment yields from a mountain catchment in the Western High Atlas region, Morocco. CATENA. https://doi.org/10.1016/j.catena.2020.104560

[23] Gourfi, A., Daoudi, L. \& Shi, Z. (2018). The assessment of soil erosion risk, sediment yield and their controlling factors on a large scale: Example of Morocco. Journal of African Earth Sciences, 147(December 2017), 281-299. https://doi.org/10.1016/j.jafrearsci.2018.06.028

[24] Govers, G. (2011). Misapplications and Misconceptions of Erosion Models. In Handbook of Erosion Modelling. https://doi.org/10.1002/9781444328455.ch7

[25] Hengl, T., Heuvelink, G. B. M., Kempen, B., Leenaars, J. G. B., Walsh, M. G., Shepherd, K. D., Sila, A., MacMillan, R. A., De Jesus, J. M., Tamene, L. \& Tondoh, J. E. (2015). Mapping soil properties of Africa at $250 \mathrm{~m}$ resolution: Random forests significantly improve current predictions. PLOS ONE. https://doi.org/10.1371/journal.pone.0125814

[26] Hovius, N., Meunier, P., Lin, C. W., Chen, H., Chen, Y. G., Dadson, S., Horng, M. J. \& Lines, M. (2011). Prolonged seismically induced erosion and the mass balance of a large earthquake. Earth and Planetary Science Letters, 304(3-4). https://doi.org/10.1016/j.epsl.2011.02.005

[27] Hovius, N., Stark, C. P., Hao-Tsu, C. \& Jiun-Chuan, L. (2000). Supply and removal of sediment in a landslide-dominated mountain belt: Central Range, Taiwan. Journal of Geology, 108(1). https://doi.org/10.1086/314387

[28] ICCD. (2008). The 10-year strategic plan and framework to enhance the implementation of the Convention (Decision 3/COP8). English. https://doi.org/Decision 3/COP.8

[29] Jain, S. K. (2001). Development of integrated sediment rating curves using ANNS. Journal of Hydraulic Engineering. https://doi.org/10.1061/(ASCE)0733-9429(2001)127:1(30)

[30] Jeong, K. S., Joo, G. J., Kim, H. W., Ha, K. \& Recknagel, F. (2001). Prediction and elucidation of phytoplankton dynamics in the Nakdong River (Korea) by means of a recurrent artificial neural network. Ecological Modelling. https://doi.org/10.1016/\$0304-3800(01)00300-3

[31] Kisi, O., Karahan, M. E. \& Şen, Z. (2006). River suspended sediment modelling using a fuzzy logic approach. Hydrological Processes, 20(20). https://doi.org/10.1002/hyp.6166

[32] Lahlou, a. (1988). The silting of Moroccan dams. IAHS Publication.

[33] Lahlou, A. (1982). LA DEGRADATION SPECIFIQUE DES BASSINS VERSANTS ET SON IMPACT SUR L'ENVASEMENT DES BARRAGES. IAHS-AISH Publication.

[34] Licciardello, F., Govers, G., Cerdan, O., Kirkby, M. J., Vacca, A. \& Kwaad, F. J. P. M. (2009). Evaluation of the PESERA model in two contrasting environments. Earth Surface Processes and Landforms, 34(5). https://doi.org/10.1002/esp.1745

[35] Liu, Q. J., Shi, Z. H., Fang, N. F., Zhu, H. De \& Ai, L. (2013a). Modelling the daily suspended sediment concentration in a hyper-concentrated river on the Loess Plateau, China, using the Wavelet-ANN approach. Geomorphology. https://doi.org/10.1016/j.geomorph.2013.01.012

[36] Liu, Q. J., Shi, Z. H., Fang, N. F., Zhu, H. De \& Ai, L. (2013b). Modelling the daily suspended sediment concentration in a hyper concentrated river on the Loess Plateau, China, using the Wavelet-ANN approach. Geomorphology, 186, 181-190. https://doi.org/10.1016/j.geomorph.2013.01.012

[37] MEA. (2003). Ecosystems and human well-being: a synthesis. Millennium ecosystem assessment. In A Framework for Assessment.

[38] Merritt, W. S., Letcher, R. A. \& Jakeman, A. J. (2003). A review of erosion and sediment transport models. Environmental Modelling and Software. https://doi.org/10.1016/S1364-8152(03)00078-1

[39] Milliman, J. D. \& Farnsworth, K. L. (2011). River discharge to the coastal ocean: A global synthesis. In River Discharge to the Coastal Ocean: A Global Synthesis. https://doi.org/10.1017/СBO9780511781247

[40] Milliman, J. D. \& Syvitski, J. P. M. (1992). Geomorphic/Tectonic Control of Sediment Discharge to the Ocean: The Importance of Small Mountainous Rivers. The Journal of Geology. https://doi.org/10.1086/629606

[41] Montgomery, D. R. \& Brandon, M. T. (2002). Topographic controls on erosion rates in tectonically active mountain ranges. Earth and Planetary Science Letters, 201(3-4). https://doi.org/10.1016/S0012-821X(02)00725-2

[42] Morgan, R. P. C. \& Nearing, M. A. (2011). Handbook of Erosion Modelling. In Handbook of Erosion Modelling. https://doi.org/10.1002/9781444328455

[43] Nagy, H. M., Watanabe, K. \& Hirano, M. (2002). Prediction of sediment load concentration in rivers using artificial neural network model. Journal of Hydraulic Engineering. https://doi.org/10.1061/(ASCE)0733-9429(2002)128:6(588)

[44] Nash, J. E. \& Sutcliffe, J. V. (1970). River flow forecasting through conceptual models part I — A discussion of principles. Journal of Hydrology. https://doi.org/10.1016/0022-1694(70)90255-6

[45] Nearing, M. A. (2006). Can soil erosion be predicted? In Soil Erosion and Sediment Redistribution in River Catchments: Measurement, Modelling and Management. https://doi.org/10.1079/9780851990507.0145

[46] Notebaert, B., Verstraeten, G., Vandenberghe, D., Marinova, E., Poesen, J. \& Govers, G. (2011). Changing hillslope and fluvial Holocene sediment dynamics in a Belgian loess catchment. Journal of Quaternary Science. https://doi.org/10.1002/jqs.1425

[47] Pisoni, E., Farina, M., Carnevale, C. \& Piroddi, L. (2009). Forecasting peak air pollution levels using NARX models. Engineering Applications of Artificial Intelligence. https://doi.org/10.1016/j.engappai.2009.04.002

[48] Plata-Bedmar, A., Cobo-Rayan, R., Sanz Montero, E., Gómez Montaña, J. L. \& Avendaño-Salas, C. (1997). Influence of the Puentes reservoir operation procedure on the sediment accumulation rate between 1954-1994. . Dix-Neuvième Congrès Des Grands Barrages.

[49] Poesen, J. W. A., Torri, D. B. \& Van Walleghem, T. (2011). Gully Erosion: Procedures to Adopt When Modelling Soil Erosion in Landscapes Affected by Gullying. In Handbook of Erosion Modelling. https://doi.org/10.1002/9781444328455.ch19

[50] Poujol, A., Ritz, J. F., Tahayt, A., Vernant, P., Condomines, M., Blard, P. H., Billant, J., Vacher, L., Tibari, B., Hni, L. \& Idrissi, A. K. (2014). Active tectonics of the Northern Rif (Morocco) from geomorphic and geochronological data. Journal of Geodynamics. https://doi.org/10.1016/j.jog.2014.01.004

[51] Qian, L., Winfree, E. \& Bruck, J. (2011). Neural network computation with DNA strand displacement cascades. Nature. https://doi.org/10.1038/nature10262

[52] Rabus, B., Eineder, M., Roth, A. \& Bamler, R. (2003). The shuttle radar topography mission - A new class of digital elevation models acquired by spaceborne radar. ISPRS Journal of Photogrammetry and Remote Sensing. https://doi.org/10.1016/S0924-2716(02)00124-7 
[53] Rajaee, T., Mirbagheri, S. A., Zounemat-Kermani, M. \& Nourani, V. (2009). Daily suspended-sediment concentration simulation using ANN and neuro-fuzzy models. Science of the Total Environment, 407(17). https://doi.org/10.1016/j.scitotenv.2009.05.016

[54] Renard, K. G., Foster, G. R., Weesies, G. A., McCool, D. K. \& Yoder, D. C. (1997). Predicting soil erosion by water: a guide to conservation planning with the Revised Universal Soil Loss Equation (RUSLE). USDA Agriculture Handbook. https://doi.org/DC0-16-048938-5 65-100.

[55] Rouai, M. \& Jaaidi, E. B. (2003). Scaling properties of landslides in the Rif mountains of Morocco. Engineering Geology. https://doi.org/10.1016/S0013-7952(02)00237-5

[56] Rymszewicz, A., Bruen, M., O'Sullivan, J. J., Turner, J. N., Lawler, D. M., Harrington, J. R., Conroy, E. \& Kelly-Quinn, M. (2018). Modelling spatial and temporal variations of annual suspended sediment yields from small agricultural catchments. Science of the Total Environment, 619-620, 672-684. https://doi.org/10.1016/j.scitotenv.2017.10.134

[57] SECEE. (2011). No Title.

[58] Simonneaux, V., Cheggour, A., Deschamps, C., Mouillot, F., Cerdan, O. \& Le Bissonnais, Y. (2015). Land use and climate change effects on soil erosion in a semi-arid mountainous watershed (High Atlas, Morocco). Journal of Arid Environments. https://doi.org/10.1016/j.jaridenv.2015.06.002

[59] Trimble, S. W. (1999). Decreased rates of alluvial sediment storage in the Coon Creek Basin, Wisconsin, 1975-93. Science, 285(5431). https://doi.org/10.1126/science.285.5431.1244

[60] Van Rompaey, A., Bazzoffi, P., Jones, R. J. A. \& Montanarella, L. (2005). Modelling sediment yields in Italian catchments. Geomorphology, 65(1-2), 157-169. https://doi.org/10.1016/j.geomorph.2004.08.006

[61] Vanmaercke, M., Poesen, J., Verstraeten, G., de Vente, J. \& Ocakoglu, F. (2011). Sediment yield in Europe: Spatial patterns and scale dependency. Geomorphology. https://doi.org/10.1016/j.geomorph.2011.03.010

[62] Verstraeten, G. \& Poesen, J. (2001). Factors controlling sediment yield from small intensively cultivated catchments in a temperate humid climate. Geomorphology. https://doi.org/10.1016/S0169-555X(01)00040-X

[63] Verstraeten, Gert \& Poesen, J. (1999). The nature of small-scale flooding, muddy floods and retention pond sedimentation in central Belgium. Geomorphology. https://doi.org/10.1016/S0169-555X(99)00020-3

[64] Verstraeten, Gert, Poesen, J., de Vente, J. \& Koninckx, X. (2003). Sediment yield variability in Spain: A quantitative and semiqualitative analysis using reservoir sedimentation rates. Geomorphology. https://doi.org/10.1016/S0169-555X(02)00220-9

[65] Wainwright, J., Parsons, A. J., Müller, E. N., Brazier, R. E., Powell, D. M. \& Fenti, B. (2008). A transport-distance approach to scaling erosion rates: I. Background and model development. Earth Surface Processes and Landforms, 33(5). https://doi.org/10.1002/esp.1624

[66] Walling, D. E. (1984). The sediment yields of African rivers. In Challenges in African Hydrology and Water Resources (Proceedings of the Harare Symposium, July 1984). IAHS Publ. no. 144.

[67] Wischmeier, W. H. (1976). Use and misuse of universal soil loss equation. Journal of Soil and Water Conservation.

[68] Wisser, D., Frolking, S., Hagen, S. \& Bierkens, M. F. P. (2013). Beyond peak reservoir storage? A global estimate of declining water storage capacity in large reservoirs. Water Resources Research. https://doi.org/10.1002/wrcr.20452

[69] Wold, H. (1966). Estimation of Principal Components and Related Models by Iterative Least-squares. Academic Press, New York.

[70] Zouhri, L., Lamouroux, C., Vachard, D. \& Pique, A. (2005). Evidence of flexural extension of the Rif foreland: The Rharb-Mamora basin (northern Morocco). Bulletin de La Societe Geologique de France. https://doi.org/10.2113/173.6.509 